\title{
Analisa Kekerasan dan Ketebalan Permukaan Lapisan Hasil Elektroplating Kuningan Pada Baja
}

\author{
Rakiman ${ }^{1}$, Hanif $^{2}$, Menhendry ${ }^{3}$, Maimuzar ${ }^{4}$, Yuli Yetri ${ }^{5^{*}}$

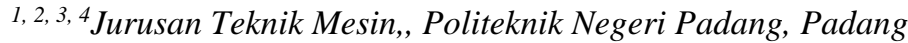 \\ *yuliyetri@pnp.ac.id
}

\begin{abstract}
Corrosion is a spontaneous process that occurs in metals due to environmental influences. The formation of corrosion on metal surfaces cannot be prevented, but the rate of corrosion can be slowed down. One of the efforts to slow down the corrosion rate is by electroplating the metal surface.The electroplating process of brass on low-carbon steel ST-37 has been carried out with variations in time of 10 minutes, 15 minutes, 20 minutes and 25 minutes and variations in the temperature of the electrolyte solution at $40^{\circ} \mathrm{C}, 45^{\circ} \mathrm{C}, 50^{\circ} \mathrm{C}$, and $55^{\circ} \mathrm{C}$. Characterization of layers using a stereo microscope and hardness with the Vicker hard test. The test results show that the increase in time and temperature is directly proportional to the thickness and hardness produced. The lowest thickness and hardness values were found at $40^{\circ} \mathrm{C}$ with a time of 10 minutes $11.323 \mu \mathrm{m} 182.4 \mathrm{VHN}$, and the highest mean thickness and hardness values were obtained at 25 minutes with a temperature of $55^{\circ} \mathrm{C}$, namely $29.333 \mu \mathrm{m}$ and $218.8 \mathrm{VHN}$. From the results obtained, it can be concluded that the increase in time and temperature given is directly proportional to thickness and hardness. The highest thickness and hardness values were obtained at 25 minutes with a solution temperature of $55^{\circ} \mathrm{C}$.
\end{abstract}

Keywords: Steel, Brass, Electrolyte, Time, Temperature

\begin{abstract}
Abstrak
Korosi merupakan proses spontan yang terjadi pada logam karena pengaruh lingkungan. Terbentuknya korosi dipermukaan logam tidak bisa dicegah, tetapi bisa diperlambat proses terjadinya. Salah satu usaha untuk memperlambat laju korosi adalah dengan melakukan pelapisan (elektroplating) pada permukaan logam tersebut. Telah dilakukan proses elektroplating kuningan pada baja karbon rendah ST-37 dengan variasi waktu 10 menit, 15 menit, 20 menit dan 25 menit serta variasi suhu larutan elektrolit $40^{\circ} \mathrm{C}, 45^{\circ} \mathrm{C}, 50^{\circ} \mathrm{C}$, dan $55^{\circ} \mathrm{C}$. Karakteristisasi lapisan dilakukan dengan menggunakan mikroskop stereo dan kekerasan dengan uji keras Vicker. Hasil pengujian menunjukan bahwa peningkatan waktu dan suhu berbanding lurus dengan ketebalan dan kekerasan yang dihasilkan. Nilai ketebalan dan kekerasan terendah ditemukan pada $40^{\circ} \mathrm{C}$ dengan waktu 10 menit $11,323 \mu \mathrm{m} \mathrm{182,4} \mathrm{VHN}$, dan nilai rata-rata ketebalan dan kekerasan tertinggi diperoleh pada 25 menit dengan suhu $55^{\circ} \mathrm{C}$ yaitu $29,333 \mu \mathrm{m}$ dan $218,8 \mathrm{VHN}$. Dari hasil yang diperoleh dapat disimpulkan bahwa peningkatan waktu dan suhu yang diberikan berbanding lurus dengan ketebalan dan kekerasan. Nilai ketebalan dan kekerasan tertinggi diperoleh pada 25 menit dengan suhu larutan $55^{\circ} \mathrm{C}$.
\end{abstract}

Kata kunci: Baja, Kuningan; Elektrolit, Waktu, Temperatur

\section{Pendahuluan}

Korosi merupakan reaksi spontan yang terjadi pada logam yang dapat mempengaruhi sifat mekanik dan umur pakai material. Untuk mengurangi laju korosif dari material yang berbahan dasar logam, diperlukan sentuhan akhir agar diperoleh barang yang berkualitas, penampilan lebih menarik dan tahan lama[1], [2]. Ada beberapa metode untuk memperlambat laju korosi seperti: elektroplating, galvanizing, painting, anodizing, proteksi katodik/anodik [2], [3], [4]. Pelapisan merupakan salah satu usaha untuk memperlambat laju korosi pada permukaan logam. Salah satu metode pelapisan 
yang biasa dilakukan pada logam adalah elektroplating. Elektroplating adalah proses pelapisan logam pada permukaan logam yang menggunakan prinsip elektrolisa [2], [3]. Metode ini merupakan suatu cara yang dilakukan untuk memberikan sifat tertentu pada suatu permukaan benda kerja dimana diharapkan benda tersebut akan mengalami perbaikan maupun ketahanannya serta tidak menutup kemungkinan pula terjadi perbaikan terhadap sifat fisiknya [4].

Saat ini finishing akhir dalam pengerjaan logam merupakan bidang yang banyak digeluti dan sangat luas penggunaannya, contohnya adalah metode elektroplating. Elektroplating logam dengan logam lainnya banyak digunakan sebagai media untuk memperindah penampilan. Prosesnya dengan cara memberikan lapisan tipis pada permukaan logam substrat dengan menggunakan logam yang memiliki keunggulan dari segi properti, ketahanan terhadap korosi, dan memperidah penampilan [4], [5], [6]. Syarat terlaksananya proses elektroplating harus ada elektroda yang terdiri dari anoda, katoda, dan elektrolit garam dari anodanya, dengan rangkaian dasar elektroplating seperti pada Gambar 1.

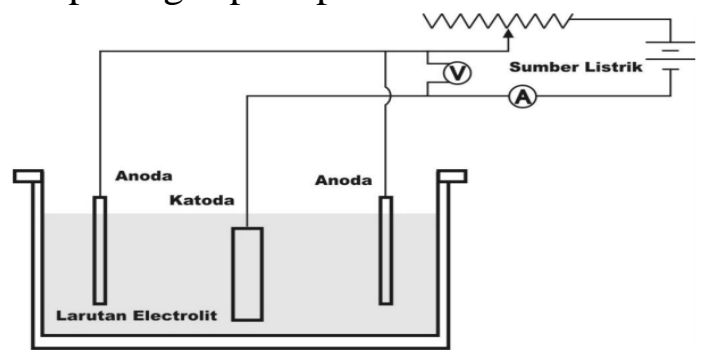

Gambar 1. Rangkaian dasar untuk elektroplating [6]

Pada proses elektroplating, logam yang dilapisi berfungsi sebagai katoda (elektroda negatif), sedangkan logam pelapis sebagai anoda (elektroda positif). Dalam proses tersebut, arus mengalir dari kutub positif ke kutub negatif sedangkan aliran elektron mengalir dari kutub negatif ke kutub positif, dengan menggunakan arus searah (DC) [7].

Mekanisme terjadinya pelapisan logam dimulai dari dikelilinginya ion-ion logam oleh melekul-molekul pelarut yang mengalami polarisasi. Di dekat permukaan katoda, terbentuk daerah Electrical Double Layer ( $E D L)$ yang bertindak seperti lapisan dielektrik. Adanya lapisan EDL memberi beban tambahan bagi ion-ion untuk menembusnya. Dengan gaya dorong beda potensial listrik dan dibantu oleh reaksi kimia, ion-ion logam akan menuju permukaan katoda, dan menangkap elektron dari katoda sambil mendeposisikan diri di permukaan katoda. Dalam kondisi equilibrium setelah ion-ion mengalami discharge menjadi atom-atom, kemudian akan menempatkan diri pada permukaan katoda dengan mengikuti susunan atom dari material katoda [7], [8].

Sedangkan kuningan merupakan logam paduan antara seng $(\mathrm{Zn})$ dengan tembaga $(\mathrm{Cu})$ sebagai pemadu utama serta beberapa elemen lainnya dalam jumlah kecil. Logam ini banyak digunakan sebagai pelapis karena mempunyai ketahanan panas dan ketahanan korosinya, tidak rusak oleh air kali atau air laut dan alkali, akan tetapi kuningan bisa rusak oleh asam nitrat dan sedikit terkorosi oleh asam khlorida dan asam sulfat [2], [10], [11]. Data karakteristik dari logam kuningan dapat dilihat pada Tabel 1.

Tabel 1. Data karakteristik kuningan [8]

\begin{tabular}{ll}
\hline Kriteria & Spesifikasi \\
\hline Titik lebur & $1453^{\circ} \mathrm{C}$ \\
Titik didih & $2913^{\circ} \mathrm{C}$ \\
Massa atom & $58,6934 \mathrm{gr} / \mathrm{mol}$ \\
Massa jenis & $8,908 \mathrm{gr} / \mathrm{cm}^{3}$ \\
Struktur kristal & $\mathrm{FCC}$ \\
Kalor peleburan & $17,48 \mathrm{~kJ} / \mathrm{mol}$ \\
Kalor penguapan & $377,5 \mathrm{~kJ} / \mathrm{mol}$ \\
\hline
\end{tabular}

Pelapisan kuningan pada besi saat ini banyak sekali diaplikasikan baik untuk tujuan pencegahan karat ataupun untuk menambah keindahan permukaan karena hasil lapisannya yang mengkilap. Jenis lain dari pelapisan kuningan adalah pelapisan yang berwarna hitam. Warna hitam inipun tampak menarik dan biasanya digunakan untuk melapis laras senapan dan lainnya. Beberapa keunggulan kuningan adalah bersifat tahan karat, dan 
dalam keadaan murni kuningan bersifat lembek, tetapi jika dipadukan dengan besi, krom, dan logam lainnya, dapat membentuk baja tahan karat yang keras [4], [9], [10].

Baja karbon adalah paduan besi dan karbon dimana unsur karbonnya sangat menentukan sifat mekanik dan fisik, sedangkan unsur paduan yang lainnya bersifat sebagai pendukung.

Tabel 2. Komposisi Baja Karbon Rendah ST 37 [11]

\begin{tabular}{cc}
\hline Unsur & Kandungan(\%) \\
\hline Fe & 99.31 \\
$\mathbf{M n}$ & 0.375 \\
$\mathbf{C}$ & 0.118 \\
$\mathbf{S i}$ & 0.555 \\
$\mathbf{W}$ & 0.46 \\
$\mathbf{S}$ & 0.015 \\
$\mathbf{C o}$ & 0.007 \\
$\mathbf{N b}$ & 0.006 \\
$\mathbf{C u}$ & Max 0,004 \\
$\mathbf{M o}$ & Max 0,004 \\
\hline
\end{tabular}

Penelitian ini menggunakan baja ST 37, dengan kekuatan tarik $\leq 37 \mathrm{~kg} / \mathrm{mm}^{2}$, dengan komposisi seperti pada Tabel 2. Baja ST 37 merupakan baja karbon rendah, karena mempunyai kandungan karbon kurang dari 0,3 $\%$ dan lebih dari $99 \%$ besi. Sifat baja karbon rendah ini mudah teroksidasi, memiliki kekuatan yang relatif rendah, keuletan yang baik, dan banyak diaplikasikan untuk tabung, pipa dan komponen mesin berkekuatan rendah.

\section{Metode Penelitian}

\subsection{Bahan dan peralatan yang diperlukan}

Bahan yang dipakai pada penelitian ini adalah: plat baja ST 37 sebagai katoda dengan dimensi panjang $35 \mathrm{~mm}$, lebar $35 \mathrm{~mm}$ dan tebal $4 \mathrm{~mm}$ sebanyak 16 buah. Anoda yang dipakai adalah kuningan (pelapis dasar) dengan dimensi $80 \mathrm{~mm}$ x $30 \mathrm{~mm}$ dan tebal $1 \mathrm{~mm}$ dengan waktu pelapisan 1 menit. Larutan elektrolit yang digunakan dalam pelapisan adalah elektolit untuk pelapisan kuningan.

Peralatan yang dipakai dalam penelitian ini adalah: Amplas belt, Poles Nanofin, Bak Pelapisan, Termostat, Stopwatch, Dryer.
Neraca Digital. Alat uji yang digunakan untuk pengujian hasil spesimen adalah: Vicker Hardness Tester, dan Mikroskop Optik.

\subsection{Pelaksanaan Penelitian}

Penelitianini akan dilakukan dalam beberapa tahap, dengan uraian pekerjaannya sebagai berikut:

- Spesimen dibersihkan secara mekanis dengan amplas dan poles. Kemudian dilanjutkan pembersihan kimiawi dengan mencelupkan ke dalam larutan $\mathrm{NaOH}$, aquades, $\mathrm{HCl}$ dan kembali dibilas dengan aquades.

- Anoda dihubungkan dengan kutub positif sumber arus dan katoda pada kutub negatif yang telah dicelupkan ke larutan elekrolit dan alirkan arus listrik.

- Pelapisan kuningan dilakukan pada tegangan 4 volt, arus 2 ampere, waktu 1 menit, dan kecepatan putaran 50rpm dengan 4 variasi temperatur elektrolit yaitu: $40{ }^{\circ} \mathrm{C}$, $45{ }^{\circ} \mathrm{C}, 50{ }^{\circ} \mathrm{C}, 55^{\circ} \mathrm{C}$ dengan waktu $10,15,20$ dan 25 menit.

- Hasil pelapisan dibersihkan dengan aquades, kemudian dikeringkan.

- Lakukan pengukuran kekerasan, dan ketebalan pada permukaan spesimen hasil elektroplating tersebut.

- Metode pengujian kekerasan Vickers dilaksanakan dengan cara menekan benda uji atau spesimen dengan indentor intan yang berbentuk piramida dengan alas segi empat dan besar sudut dari permukaanpermukaan yang berhadapan $136^{\circ}$. Penekanan oleh indentor akan menghasilkan suatu jejak atau lekukan pada permukaan benda uji, seperti pada Gambar 2.
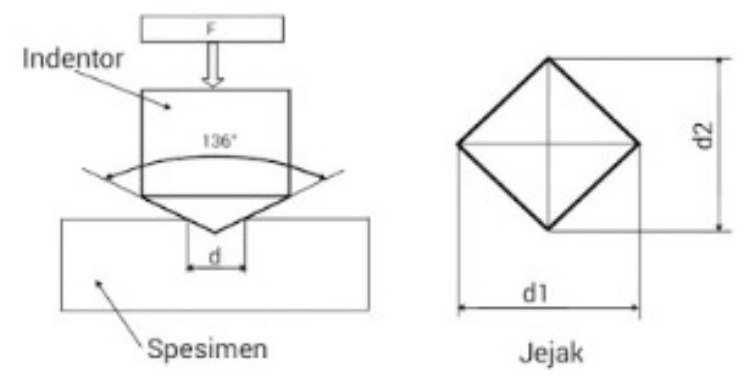

Gambar 2. Bentuk bekas penekanan indentor 
Untuk mengetahui nilai kekerasan benda uji, maka diagonal rata-rata dari jejak tersebut harus diuiur terlebih dahulu dengan memakai mikroskop. Angka kekerasan Vickers dapat diperoleh dengan membagi besar beban uji yang digunakan dengan luas permukaan jejak menggunakan persamaan berikut ini..

$$
H V=\frac{P}{A}
$$

Dimana $\mathrm{HV}=$ angka kekerasan Vickers $\mathrm{P}=$ beban benda uji, dan $\mathrm{A}=$ luas permukaan jejak. Untuk lebih jelasnya tahapan pengerjaan penelitian ini dapat dilihat diagram alir pada Gambar 3.

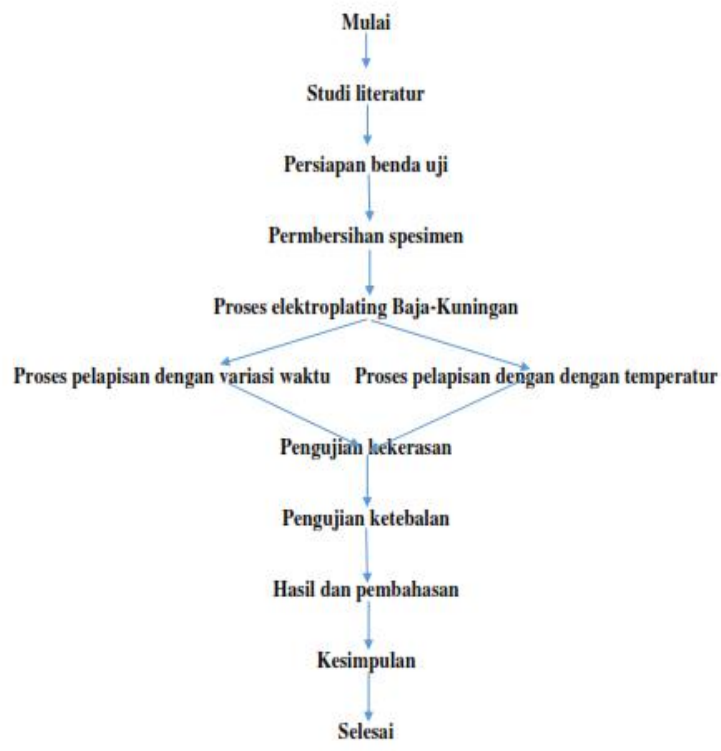

Gambar 3. Diagram alir tahap-tahap pengerjaan

\section{Hasil dan Pembahasan}

\subsection{Pengujian Ketebalan}

Pengambilan data nilai ketebalan dilakukan dengan pemilihan 3 titik data yang ditarik secara garis lurus (horizontal). Dari serangkaian pengujian yang sudah diakukan terlihat bahwa terjadi penambahan ketebalan/ massa dengan kenaikan temperatur. Penambahan ketebalan/ massa pelapisan dihitung dengan selisih massa awal dan massa setelah proses elektroplating. Data dan kenaikkan ketebalan/ masa yang didapatkan dirangkum dalam bentuk grafik seperti pada Gambar 3.

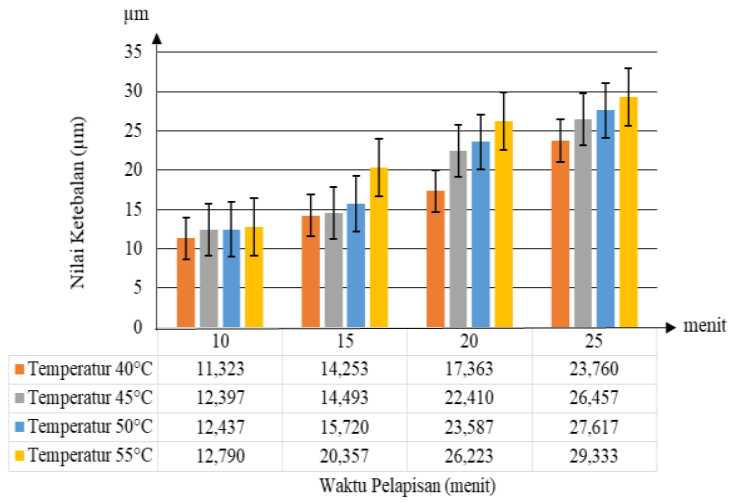

Gambar 3. Nilai ketebalan dengan variasi waktu dan temperatur

Pada Gambar 3 dapat dilihat bahwa penambahan massa berbanding lurus terhadap waktu dan temperatur larutan proses elektroplating. Nilai pertambahan massa pada variasi temperatur kurang menunjukkan kenaikan yang signifikan, sedangkan pada variasi waktu pertambahan massanya lebih signifikan. Sesuai dengan hukum Faraday yang menyatakan massa lapisan yang bertambah dipengaruhi oleh arus dan waktu proses elektroplating [4], [11]. Pada hasil pengujian dapat dilihat bahwa pertambahan tebal terkecil terletak pada temperatur $40^{\circ} \mathrm{C}$ dan lama proses elektroplating 10 menit yaitu sebesar 11,323 $\mu \mathrm{m}$. Sedangkan penambahan ketebalan terbesar terletak pada proses elektroplating selama 25 menit dan temperatur $55^{\circ} \mathrm{C}$ yaitu sebasar 29,33 $\mu \mathrm{m}$.

\subsection{Pengujian Kekerasan}

Pada pengujian kekerasan dilakukan pengambilan 5 titik uji pada spesimen baja ST 37 dan pelapisan kuningan pada baja. Nilai kekerasan dari baja sebelum dilapisi seperti dapat dilihat pada Tabel 3, dengan rata-rata kekerasan 164,8 HVN.

Gambar 4 memperlihatkan nilai kekerasan rata-rata hasil pelapisan bajakuningan variasi waktu dan temperatur. Gambar tersebut menunjukkan dengan kenaikan waktu pelapisan dan temperatur larutan yang diberikan maka nilai kekerasan semakin tinggi dan hal ini berbanding lurus 
dengan kenaikan nilai ketebalan [5], [13], [14]. Hal ini juga tidak terlepas dari faktor yang mempengaruhi proses elektroplating yaitu jenis material yang digunakan, waktu, temperatur dan perpindahan ion itu sendiri [6]. Pada waktu 10 menit dan temperatur $55^{\circ} \mathrm{C}$ memiliki nilai kekerasan permukaan sebesar 198,8 VHN. Sedangkan pada waktu 25 menit dengan temperatur yang sama memiliki nilai kekerasan yang lebih tinggi dari waktu pelapisan 10, 15 dan 20 menit yaitu 218,8 VHN. Hal ini menunjukkan bahwa semakin lama waktu pelapisan semakin banyak ion yang melekat pada katoda dan semakin besar massa yang mengendap di katoda, sesuai dengan hukum Faraday [5], [13], [16].

Tabel 3. Data uji keras pada spesimen baja

\begin{tabular}{cc}
\hline Titik Uji & $\begin{array}{c}\text { Kekerasan } \\
\text { (HVN) }\end{array}$ \\
\hline $\mathbf{1}$ & 166 \\
$\mathbf{2}$ & 163 \\
$\mathbf{3}$ & 164 \\
$\mathbf{4}$ & 168 \\
$\mathbf{5}$ & 163 \\
\hline Rata-rata & 164,8 \\
\hline
\end{tabular}

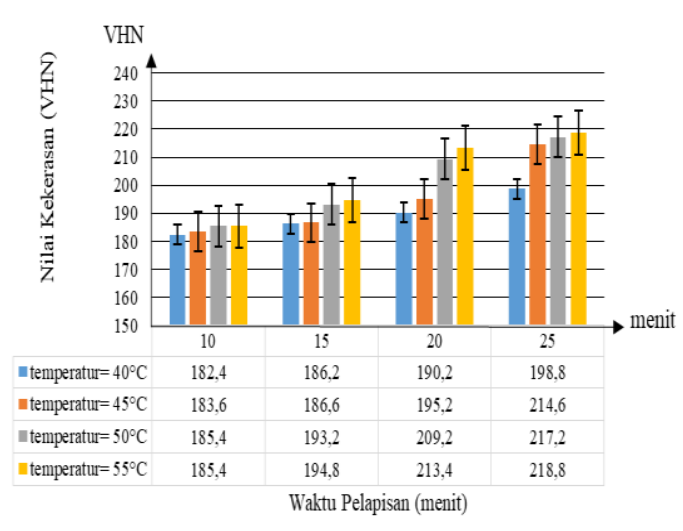

Gambar 4. Nilai kekerasan dengan variasi waktu dan temperatur

Hal ini menunjukan semakin tinggi suhu larutan, biasanya mengurangi penyerapan hidrogen ke endapan sehingga meningkatkan kekerasan permukaan lapisan. Kemudian kuningan yang digunakan sebagai pelapis merupakan paduan $\mathrm{Zn}$ dengan $\mathrm{Cu}$. Dalam proses pelapisan $\mathrm{Cu}$ yang dominan dalam membentuk lapisan di permukaan logam yang dilapisi [9]. Selain itu, peningkatan suhu dan waktu pelapisan menyebabkan ukuran butir mengalami penyusutan dan semakin banyak pula sedimen yang menempel pada katoda. [5], [7], [14].

Hasil yang diperoleh dari pengujian menunjukan bahwa peningkatan waktu dan suhu sebanding dengan ketebalan dan sifat mekanik kekerasan [15], [17]. Nilai ketebalan dan kekerasan terendah diperoleh pada temperatur $40^{\circ} \mathrm{C}$ dengan waktu pelapisan 10 menit adalah 11,323 $\mu \mathrm{m}$ dan 182,4 VHN. Sedangkan nilai rata-rata ketebalan dan kekerasan tertinggi diperoleh 29,333 $\mu \mathrm{m}$ dan 218,8 VHN pada 25 menit dengan suhu $55^{\circ} \mathrm{C}$

\section{Kesimpulan}

Dari penelitian yang dilakukan dapat disimpulkan bahwa:

a. Penambahan kekerasan dan ketebalan lapisan berbanding lurus dengan waktu, dan temperatur larutan elektrolit. Peningkatan temperatur dan waktu pelapisan yang digunakan, berbanding lurus dengan pertambah ketebalan dan kekerasan lapisan yang terbentuk.

b. Kondisi optimum diperoleh pada waktu 25 menit, dan temperatur $55^{\circ} \mathrm{C}$ yaitu ketebalan 29,333 $\mu \mathrm{m}$, dan kekerasan 218,8 HV.

\section{Saran}

Agar diperoleh hasil yang sesuai standar pelapisan logam, maka diperlukan adanya penelitian lanjutan untuk memperoleh kondisi yang optimum.

\section{Ucapan Terima kasih}

Penulis mengucapkan terima kasih yang telah membiayai penelitian ini dengan sumber dari DIPA Politeknik Negeri Padang, dengan kontrak No: 98/19PL9.1.4/AM/2020.

\section{Daftar Pustaka}

[1] Basmal, B., "Pengaruh Suhu Dan Waktu Pelapisan Tembaga-Nikel Pada Baja Karbon 
Rendah Secara Elektroplating Terhadap Nilai Ketebalan Dan Kekasaran", ROTASI, vol. 14, no. 2, pp. 23-28, April 2012.

[2] Dewi, Citra Ayu, "Pengaruh Waktu Pada Elektroplating Krom Dekoratif Dengan Logam Basis Tembaga Terhadap Laju Korosi”. Jurnal Ilmiah Pendidikan Kimia Hydrogen", vol. 1, no. 2, pp., 107-111, 2016.

[3] Hartomo, J. A., "Mengenal Pelapisan Logam (Elektroplating)", Yogyakarta: Andi Offset, 1995.

[4] Saleh, Azhar A., "Elektroplating Teknik Pelapisan Logam dengan Cara Listrik", Bandung: Yrama Widya, 2014.

[5] Yetri Y, Marsedi U, Affi J, Leni D, "Pengaruh Waktu Dan Temperatur Larutan Terhadap Ketebalan Dan Kekerasan Permukaan Lapisan Hasil Elektroplating Kuningan Pada Baja”, Manutech: Jurnal Teknologi Manufaktur, vol. 12, no. 01, pp. 55-64, 2020.

[6] Catur, A. D., Lagiyono, "Laju korosi baja karbon yang dilapisi tembaga dengan proses elektroplating pada lingkungan cair", Oseatek: Majalah Ilmiah bidang kelautan, perikanan, matematika dan teknologi, 2008.

[7] Rangkaian dasar Elektroplating. Universitas SumateraUtara.

http://repository.usu.ac.id/bitstream/12345678 9/44516/3/Chapter\%20II.pdf

[8] Widodo, S. R., "Analisa Pengaruh Variasi Temperatur Proses Pelapisan Nikel Khrom Terhadap Kualitas Ketebalan Dan Kekerasan Pada Baja ST. 40”, SNFT UMSIDA, 2013.

[9] Nanini, I. D, "Pengaruh Waktu dan Temperatur Larutan Pelapisan (Elektroplating) Kuningan pada Baja Terhadap Ketebalan dan Kekerasan Permukaan Lapisan", Skripsi, Jurusan Teknik Mesin, UNAND Padang, 2018.
[10]Kumar, S., "Factor Effecting ElectroDeposition Process", International Journal of Current Engineering and Technology. vol.5, no.2, pp. 700-703, Maret 2015

[11] Syamsa, B. S., "Pengaruh Parameter Proses Pelapisan Nikel Terhadap Ketebalan Lapisan”, Jurnal Teknik Mesin, vol. 9, no. 1, pp. 25-30, 2007

[12] Harnowo Supriadi, Z., "Pengaruh Rapat Arus Dan Temperatur Elektrolit Terhadap Ketebalan Lapisan Dan Efisiensi Katoda Pada Elektroplating Tembaga Untuk Baja Karbon Sedang”, Jurnal Mechanical, vol. 4, no. 1, pp. 30-37, 2013.

[13] Effendi, Nizam. (2009). Pengaruh Variasi Rapat Arus Terhadap Ketebalan Lapisan Elektroplating Seng Pada Baja Karbon Rendah. Yogyakarta: Jurusan Teknik Mesin, STTNAS Yogyakarta.

[14] Basmal, "Pengaruh Rapat Arus Dan Waktu Pelapisan Proses Elektroplating Terhadap Ketebalan Lapisan Krom", POLITEKNOSAINS, vol. X, no. 2, pp. 1-10, 2011.

[15]Paridawati, “Analisa Besar Pengaruh Tegangan Listrik Terhadap Ketebalan Pelapisan Chrome Pada Pelat Baja Dengan Proses Electroplating", Jurnal Ilmiah Teknik Mesin, vol. 1, no. 1, pp. 36-44, Februari 2013.

[16] Prasetyo Hani, Faid Ahmad Yafi, "Pengaruh Variasi Waktu Electroplating Nikel Terhadap Berat Lapisan Yang Diendapkan Pada Baja ST37", Jurnal MER-C, vol. 1, no. 6, pp. 1-5, 2018.

[17] Putri Andrisel, Handayani Sri, "Karakterisasi Sifat Mekanik Hasil Electroplating Nikel Karbonat $\left(\mathrm{NiCO}_{3}\right)$ Pada Tembaga $(\mathrm{Cu})$ ", Jurnal Fisika Unand, vol. 4, no. 1, pp. 83-90, Januari 2015. 